Research, part of a Special Feature on Strengthening adaptive capacity

\title{
Ecosystem Services and Human Well-Being: a Participatory Study in a Mountain Community in Portugal
}

\author{
Elvira Pereira $^{1}, \underline{\text { Cibele Queiroz }}^{2}, \underline{\text { Henrique Miguel Pereira }}^{2}$, and $_{\text {Luis Vicente }^{2}}$
}

\begin{abstract}
Ecosystem services are essential for human well-being, but the links between ecosystem services and human well-being are complex, diverse, context-dependent, and complicated by the need to consider different spatial and temporal scales to assess them properly. We present the results of a study in the rural community of Sistelo in northern Portugal that formed part of the Portugal Millennium Ecosystem Assessment. The main purpose of our study was to assess the linkages between human well-being and ecosystem services at the local level, as perceived by the community. We used a range of tools that included participatory rural appraisal and rapid rural appraisal as well as other field methods such as direct observation, familiarization and participation in activities, semistructured interviews, trend lines, wellbeing ranking, and other ranking and scoring exercises. Sistelo has a unique landscape of agricultural terraces that are now being abandoned because of the depopulation of the region, a common trend in mountainous rural areas of Europe. From the community perspective, some components of well-being such as material well-being have been improving, whereas some ecosystem services, e.g., food production, have been declining. Although a few of the local criteria for well-being are closely related to local ecosystem services, most of them are not. People recognize many of the services provided by ecosystems, in particular, provisioning, cultural, and regulating services, although they feel that provisioning services are the most important for well-being. It is apparent that, for the Sistelo community, there is an increasing disconnect between local well-being and at least some local ecosystem services. This disconnect is associated with greater freedom of choice at the local level, which gives the local inhabitants the power to find substitutes for ecosystem services. The consequences of land abandonment for human well-being and ecosystem services at different temporal and spatial scales are discussed.
\end{abstract}

Key Words: ecosystem services; human well-being; participatory rural appraisal; rapid rural appraisal; participatory study; biodiversity; rural community; land abandonment; mountain landscape; Millennium Ecosystem Assessment

\section{INTRODUCTION}

The well-being of present and future generations depends on the continuous flow of ecosystem services, which are the benefits people obtain from ecosystems (Daily 1997). Links between human well-being and ecosystem services are multiple and complex (Salzman et al. 2001). Improvements in the well-being of present generations can have negative impacts on the supply of ecosystem services to future generations if those improvements are based on unsustainable exploitation of the environment. Furthermore, there are trade-offs between ecosystem services, and different interest groups can have different priorities with regard to which ecosystems services should be enhanced to maximize the well-being of a particular group (McMichael et al., in press).

In recent years, the study of the relationship between ecosystem services and human well-being has received a fair amount of attention (Salzman et al. 2001, Michaelidou et al. 2002, Deutsch et al. 2003, Wainger and Price 2004). For instance, Deutsch et al. (2003) focused on the dependence of human 
well-being on ecosystem services at the global level and the decreasing capacity of ecosystems to continue producing those services, whereas Michaelidou et al. (2002) studied the relationship between community well-being and ecosystem viability at the local scale, noting that they are both interconnected and interdependent.

The Millennium Ecosystem Assessment (MA) was the largest study ever conducted of the linkages between ecosystems and human well-being. The MA was unique in that it was carried out at multiple scales, from the local to the regional to the global. The multiscale nature of the MA acknowledges that people and ecosystems interact in different temporal and spatial domains, as illustrated in the MA conceptual framework (Fig. 1). The conceptual framework connects human well-being, indirect drivers of change, direct drivers of change, and ecosystem services (Millennium Ecosystem Assessment 2003). Our study is part of the Portugal Sub-Global Assessment (

http://www.ecossistemas.org) of the MA, and uses the MA conceptual framework to assess the linkages between human well-being and local ecosystem services from the perspective of a rural mountain community in northern Portugal. Local communities are often the most direct link to ecosystems (Folke et al., in press), because they frequently depend on local ecosystem services and are the most directly affected by ecosystem degradation (Millennium Ecosystem Assessment 2003). Local communities may also be active managers of the local ecosystems that they depend on (Folke et al., in press). Therefore, it is essential to understand how people use, perceive, and value different ecosystem services.

Sistelo has a unique landscape of agricultural terraces that are now being abandoned because of the depopulation of the region. The abandonment of mountainous rural areas is a common trend in European countries (Baudry 1991, Farina 1997, MacDonald et al. 2000), and in recent years there has been increasing concern about the environmental, economic, and social consequences of this. The consequences of farmland abandonment for local ecosystems and their ability to provide services remain a controversial issue. This controversy is fueled by the existence of trade-offs between different ecosystem services and by the extensive temporal and spatial variability in the effects of this abandonment, which are influenced by numerous factors (MacDonald et al. 2000, Höchtl et al. 2005).
Although the conversion of abandoned agricultural land to natural habitats can have positive impacts on some species (Farina 1991), it has been argued that low-intensity agriculture in Europe has become essential to the conservation of local biodiversity and ecosystem services (Bignal and McCracken 1996, Moreira et al. 2001a). Therefore, the consequences of agricultural land abandonment for local ecosystems vary with the context and the conservation goals (Correia 1993, Burel and Baudry 1995, MacDonald et al. 2000).

Although the MA recognizes that biodiversity has an intrinsic value, it focuses mainly on the consequences of ecosystem changes for human well-being (Millennium Ecosystem Assessment 2003). Well-being is multidimensional, dynamic, complex, and context-dependent (Narayan et al. $2000 a, b)$. Therefore, it is crucial to understand local criteria for human well-being. In our study we use a participatory approach to examine both the local criteria for well-being and the links to ecosystem services. We chose a participatory approach because of the context dependence of well-being and because conventional analyses tend to disregard some fundamental aspects of well-being (Pereira 2001). Studies of local criteria for well-being received a strong impetus in the 1990s, in particular with the dissemination of Participatory Poverty Assessments or PPAs (Norton et al. 2000), which adopted methods developed in the context of Participatory Rural Appraisals (PRA) and Rapid Rural Appraisals (RRAs). During the 1990s, the World Bank conducted 81 PPAs in 50 countries around the world, and in 1999 PPAs were conducted in 23 countries under the World Bank's "Voices of the Poor" initiative (Narayan et al. 2000a,b). Participatory approaches have also been used in studies of natural resources management, agriculture, health and nutrition, poverty, and livelihoods (Sustainable Agriculture and Rural Livelihoods Programme 1988-2001, Chambers 2003).

Our study demonstrates the complex links between ecosystem services and human well-being from the perspective of a rural mountain community. We ask four questions: (1) What are the local criteria for human well-being? (2) Which ecosystem services are recognized and valued by the community? (3) What are the main trends in those services and their impacts on well-being? (4) What are the plausible futures of ecosystem services and human well-being in Sistelo? 
Fig. 1. The Millennium Assessment Conceptual Framework (Millennium Ecosystem Assessment 2003).

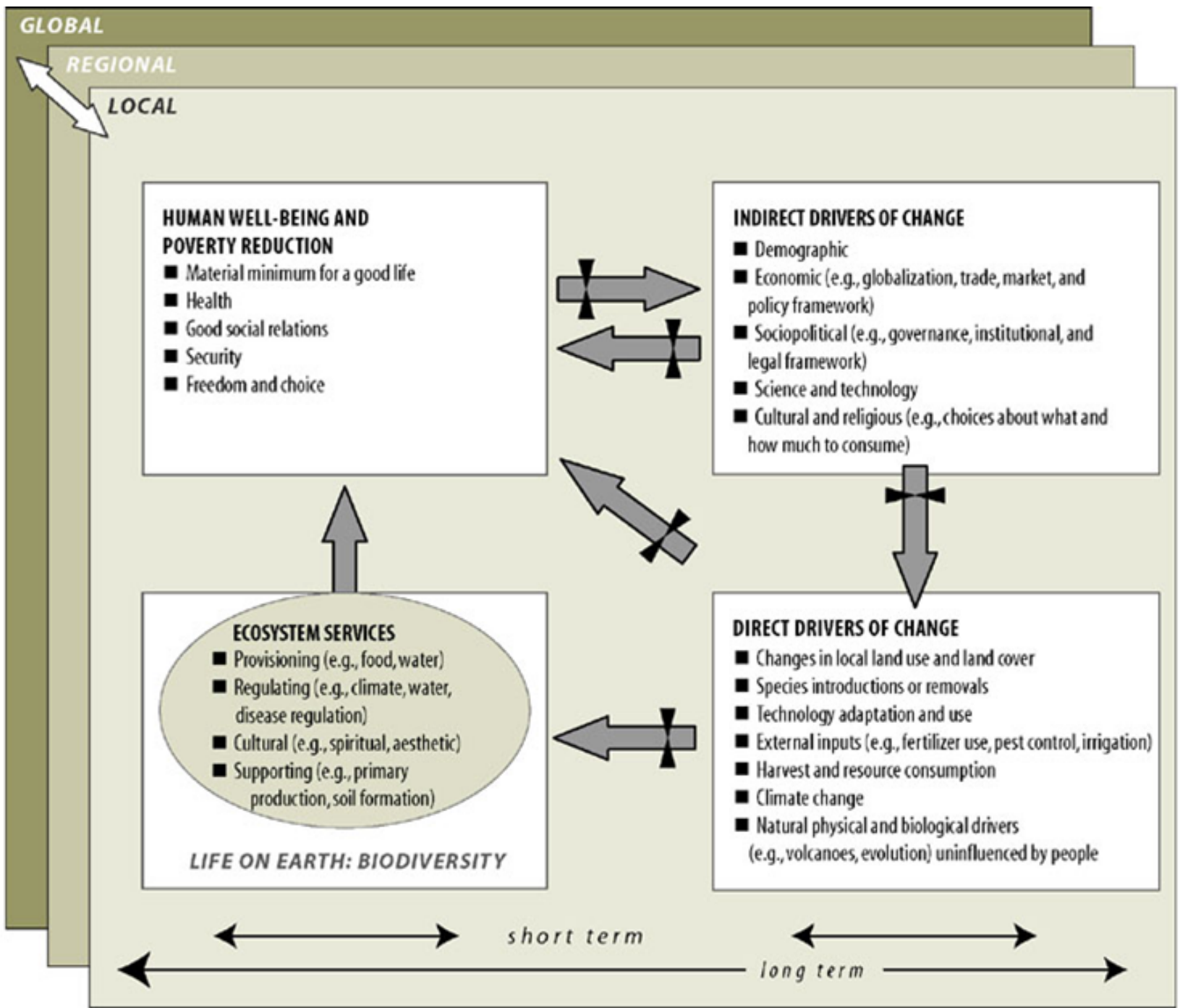

\section{STUDY AREA}

Sistelo is a rural parish in the Peneda Mountain Range in northwest Portugal (41 ${ }^{\circ} 58^{\prime} \mathrm{N}$; 8\&\#176, $22^{\prime} \mathrm{W}$ ) with an area of $26.2 \mathrm{~km}^{2}$ (Fig. 2). Its altitude ranges from $180 \mathrm{~m}$ to $1360 \mathrm{~m}$. In this region, the mean annual temperature is $13^{\circ} \mathrm{C}$, the risk of frost is high except from June to October, and the mean annual rainfall is approximately $2000 \mathrm{~mm}$; all of these are characteristics of a maritime Mediterranean climate (Rey 2000). Sistelo is composed of Igreja, Estrica, Quebrada, Padrão, and Porto Cova, five small localities isolated from one other by distance and the lack of public transportation. According to the Instituto Geográfico Português (IGP 1990), the main land uses in Sistelo are cropland (8\%), scrubland and pasture (43\%), oak forest (16\%), pine forest (11\%), urban areas (1\%), and other (21\%). 
Fig. 2. The geographic location of Sistelo, Portugal.
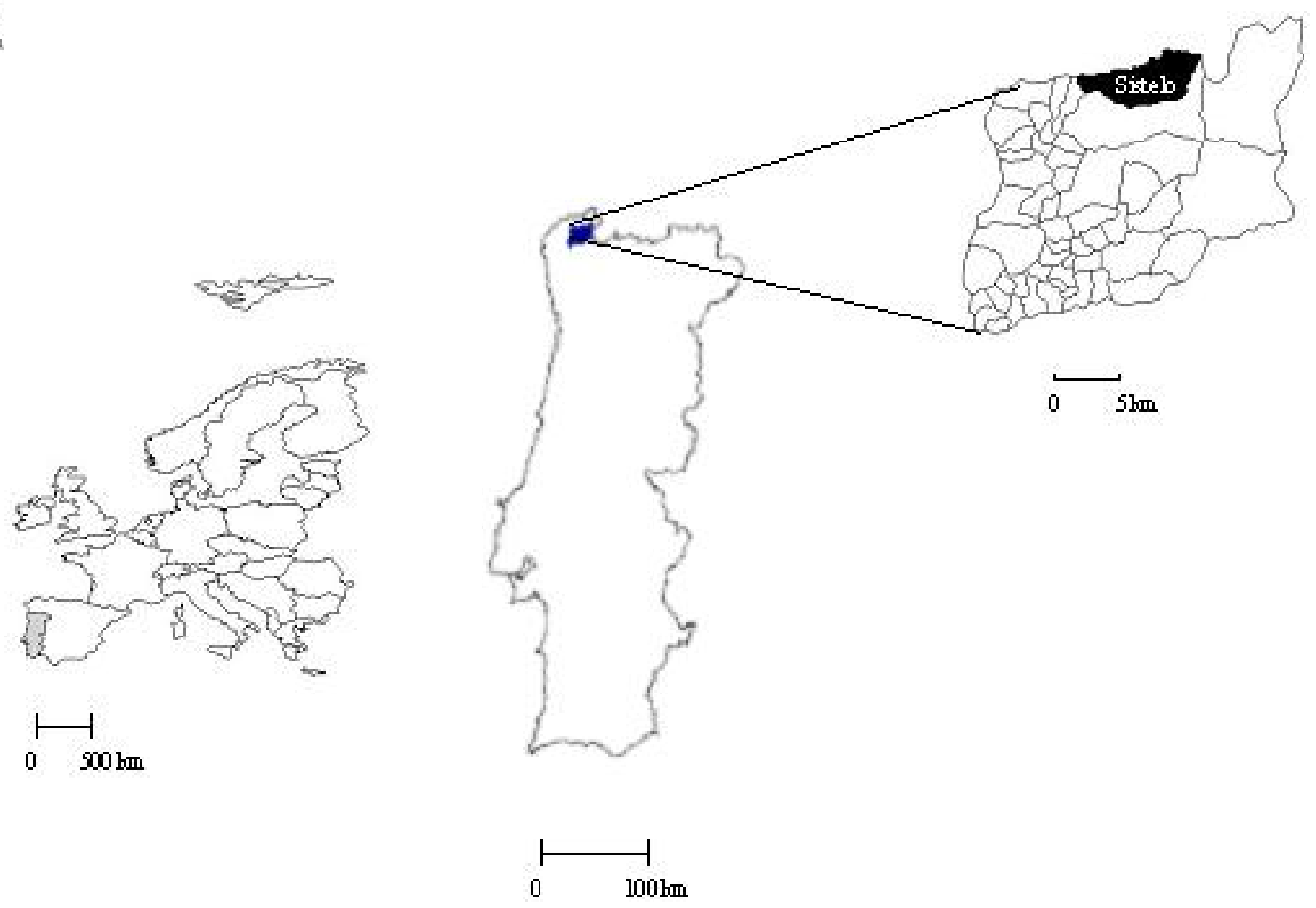

At the beginning of the 20th century, Sistelo was a rural community highly adapted to the mountainous terrain. The livelihoods of the local population were based on agro-pastoralism, and the restrictions imposed by the geography of the mountain, including steep slopes and extreme climatic conditions, led to diversified land uses. Agriculture was carried out on terraces called socalcos at successive heights on the mountain slope (Fig. 3), and the main cultivated crops were corn, potatoes, and rye (Rey 2000). Soil fertilization was assured by animal manure. Animal husbandry was supported mainly by the baldio or common property area (Medeiros 1984). The organization of pastoral life was based on the mobility of the livestock from the valleys in the winter inverneiras to the higher zones with better pastures in the summer, known locally as the brandas (Graça 1996).

After a demographic peak in the 1950s, the 1960s marked the beginning of increasing emigration to other countries (Graça 1996). The appropriation of the baldio by the State in the 1940s, followed by its afforestation, drastically reduced the area available for pasture. This imposed land-use change associated with the lack of opportunities for life improvement and the attractive situation of the labor market in foreign countries were strong incentives for emigration (Medeiros 1984). Emigration, particularly male emigration, became a livelihood strategy for families in Sistelo. By the late 1970s, the number of animals had declined, and traditional 
Fig. 3. The agricultural terraces or socalcos of Sistelo.

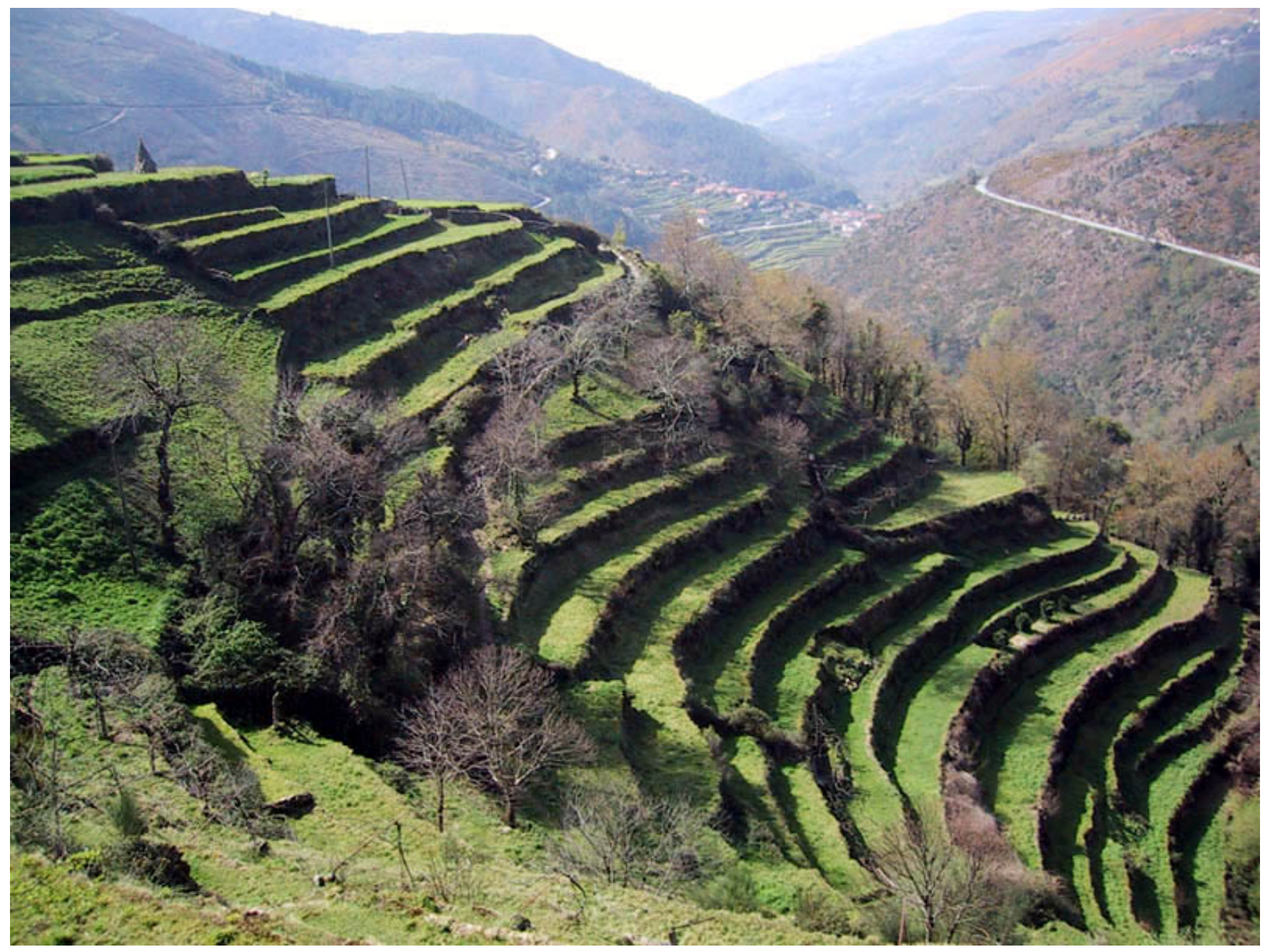

seasonal mobility strategies were being progressively abandoned despite the return of the baldio to the community in 1974. With reduced local labor because of emigration and insufficient income to hire farm workers, there was also a reduction in the area under cultivation (Caldas 1982).

The trend toward depopulation and abandonment of the fields has continued to the present. Between 1960 and 2001, the population in Sistelo decreased by $57 \%$ (INE 1964, 2001). The current number of residents in the community is 341 (INE2001). There is a high proportion of women and elderly, and the illiteracy rate is very high (Table 1 and Fig. 4).
Pensions are the main means of living (INE 2001). Other major sources of income are emigrant remittances and agricultural subsidies. The crude activity rate is $61 \%$, and about $84 \%$ of the labor force is employed in agriculture, animal husbandry, and the forestry sector (INE 2001).

With regard to access to key facilities and services, $10.6 \%$ of the resident population does not have piped water in the household, $28.7 \%$ does not have a bath or shower, $21.7 \%$ does not have a toilet, and $78.9 \%$ uses fireplaces as the only heating system (INE 2001). Health facilities are nonexistent in the 
community. Igreja, the central locality, has the only primary school, with five students.

Sistelo was proposed as a study case for the mountain system in the Portugal Millennium Ecosystem Assessment by the National Park of Peneda-Gerês (Pereira et al. 2003). Sistelo borders the National Park and is included in the recently approved Natura 2000 Network site, which spans the National Park.

Table 1. Comparison of some Sistelo sociodemographic indicators with Portuguese national averages.

\begin{tabular}{lll}
\hline \hline Indicator & Sistelo & Portugal \\
\hline $\begin{array}{l}\text { Population density } \\
\text { (persons } / \mathrm{km}^{2} \text { ) }\end{array}$ & 13 & 112 \\
$\begin{array}{l}\text { Women (\%) } \\
\text { Residents } 65 \mathrm{yr}\end{array}$ & 62 & 52 \\
$\begin{array}{l}\text { and older (\%) } \\
\begin{array}{l}\text { Illiterates } 10 \mathrm{yr} \\
\text { and older }(\%)\end{array}\end{array}$ & 36 & 16 \\
\hline
\end{tabular}

\section{METHODS}

A participatory approach was used to study wellbeing and the links between well-being and ecosystem services. This participatory approach was based on behavioral and epistemological principles shared by the Rapid Rural Appraisal (RRA) and the Participatory Rural Appraisal (PRA) approaches; these include a reversal of learning, learning rapidly and progressively with flexible use of methods, accepting appropriate imprecisions, offsetting biases, triangulating, seeking diversity, facilitating, being self-critical, and sharing information and ideas (Chambers 1992).

Participants in the study were selected using a nonprobability sample of residents in the community, i.e., no effort was made to sample each element of the population with a fixed probability. Nonprobability sampling is particularly suited to understanding qualitative and relational issues (Narayan 1996). The sample size was not determined prior to data collection. Instead, sampling was conducted sequentially in each locality and for each tool, using snowball sampling, i.e., asking key informants to name other people who should be contacted by the researchers, and accidental sampling, i.e., groups of people or individuals met randomly when walking through the localities or with key informants and available to participate. We purposely included men and women, younger and older people, people engaged in different activities, and people considered worse or better off economically if the initial sample did not reflect this diversity. This technique, known as diversity or common sense sampling, was used to ensure diversity and avoid sampling errors containing biases related to leadership, gender, age, visibility, and wealth (Narayan 1996).

For the tools for which we wanted to perform some type of quantitative data analysis, we tried to ensure that at least $10 \%$ of the residents of each of the five localities were included. We also made sure that the proportion of women and men sampled was the same as the sex ratio in the population, which is a form of quota sampling.

Because we used a combination of these sampling strategies for each tool and could not control the size of the groups casually encountered, none of the subsamples were the same size. Although we tried to ensure diversity, we cannot claim that this sample is statistically representative. Eighty-six individuals participated in this study, including 80 residents (about $24 \%$ of the population) and six nonresident key informants. Of the total participants, $61 \%$ were women, who represent $62 \%$ of the population.

After reviewing the available secondary information, we made seven visits of 3-4 d each from December 2003 to July 2004 (Table 2), plus one final meeting with local organizations in December 2004. The field methods and tools used in this research were chosen and adapted from Narayan (1996), Rietbergen-McCracken and Narayan (1998), and SEAGA (2001). They included direct observation, semistructured interviews, trend lines, ranking, and scoring. Besides these methods and tools, familiarization with the community and participation in its daily activities were considered important so that we could learn more about the community and establish a relaxed rapport and some measure of trust with the local people. The analysis of data was based mainly on frequencies of references/ responses within each of the categories created, including those made in the semistructured interviews and visual tools, and the outputs of visual 
Fig. 4. Age-structure pyramid of the Sistelo population.

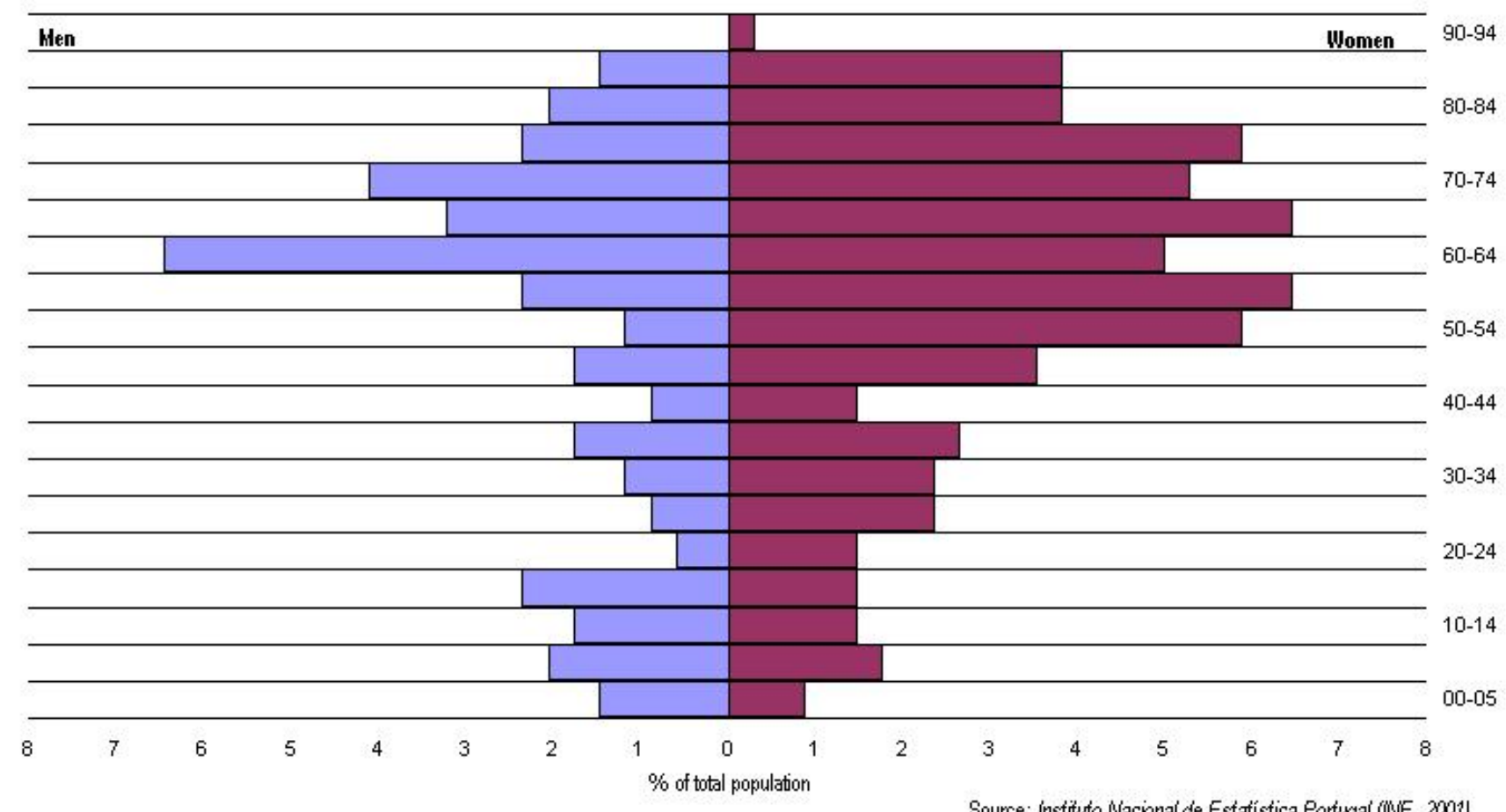

tools, which included trends, scoring, and ranking. Key anecdotes and quotes were chosen to illustrate some findings.

Fieldwork was performed by two researchers, one of whom had a background in the social sciences and the other in biology. We chose not to tape record the application of tools, so one of the researchers played the role of facilitator and the other of notetaker. To ensure the trustworthiness of our findings we triangulated the information sources, methods, and people to assess reliability or constancy of findings and used community validation of findings to assess validity, i.e., closeness of a finding to "reality."

\section{Semistructured interviews}

We performed the semistructured interviews using a flexible interview guide focused on four issues: well-being, ecosystem services, major trends, and major problems. These issues were presented in a conversational way to 18 residents. One of these residents (the priest) was selected by the researchers as a key informant, Sistelo's local authority selected one key informant in each of the five localities, and the others were purposively selected by the researchers to ensure diversity, usually by asking local residents, including key informants, to identify informants in the same locality of a different gender, age, and economic status. If these informants were with one or two other local residents when encountered, the interview would be conducted with the group. Following the interviews, the data collected were organized into categories for each of these four issues. We then created graphs and cards with cartoons and photographs to facilitate trend analysis, ranking, scoring, and the discussion of different points of view. 
Table 2. Organization of the fieldwork. Researchers also made direct observations and attempted to become familiar with and take part in community and daily activities during all the visits listed below.

\begin{tabular}{|c|c|c|c|}
\hline Visit & Tools and methods & Local participants & Location \\
\hline & $\begin{array}{l}\text { Meetings with local authority, local } \\
\text { organizations, and organizations operating in } \\
\text { the area }\end{array}$ & Key informants & Sistelo at large \\
\hline \multicolumn{4}{|l|}{$\begin{array}{l}1 \text { a- } \\
\text { nd } 2\end{array}$} \\
\hline & Semistructured interviewing & $\begin{array}{l}\text { Key informants } \\
\text { Selected individuals } \\
\text { Casual groups }\end{array}$ & The five small localities in Sistelo \\
\hline & Trend lines & $\begin{array}{l}\text { Purposively selected } \\
\text { groups: } \\
\text { 1) Young people } \\
\text { of both genders } \\
\text { 2) Middle-aged } \\
\text { and older women } \\
\text { 3) Middle-aged } \\
\text { and older men }\end{array}$ & Igreja \\
\hline \multicolumn{4}{|l|}{3} \\
\hline & Well-being ranking & $\begin{array}{l}\text { Casual groups } \\
\text { randomly encount- } \\
\text { ered } \\
\text { Selected individuals }\end{array}$ & Igreja \\
\hline 4 & $\begin{array}{l}\text { Agro-ecosystem resources } \\
\text { scoring and ranking } \\
\text { Criteria for well-being ranking }\end{array}$ & $\begin{array}{l}\text { Casual groups } \\
\text { randomly encount- } \\
\text { ered } \\
\text { Selected individuals }\end{array}$ & Igreja \\
\hline 5 & $\begin{array}{l}\text { Agro-ecosystem resources } \\
\text { scoring and ranking } \\
\text { Landscape scoring } \\
\text { Well-being ranking } \\
\text { Criteria for well-being ranking } \\
\text { Species list }\end{array}$ & $\begin{array}{l}\text { Casual groups } \\
\text { randomly encount- } \\
\text { ered } \\
\text { Selected individuals }\end{array}$ & $\begin{array}{l}\text { Padrão and } \\
\text { Porto Cova }\end{array}$ \\
\hline 6 & $\begin{array}{l}\text { Agro-ecosystem resources } \\
\text { scoring and ranking } \\
\text { Landscape scoring } \\
\text { Well-being ranking } \\
\text { Criteria for well-being ranking } \\
\text { Species list }\end{array}$ & $\begin{array}{l}\text { Casual groups } \\
\text { randomly encount- } \\
\text { ered } \\
\text { Selected individuals }\end{array}$ & $\begin{array}{l}\text { Estrica } \\
\text { Quebrada } \\
\text { Igreja }\end{array}$ \\
\hline
\end{tabular}

\section{Well-being ranking}

We used two approaches to identify relevant local criteria for well-being. Respondents were selected using accidental sampling, quota sampling, diversity sampling, and snowball sampling, e.g., by asking local residents to name people they considered worse or better off than they were. The most commonly used approach, which we introduced to 39 residents, was to ask them to (1) identify and rank different groups in the community in terms of well-being or explain what they considered the criteria of a good life, (2) rank different localities in terms of well-being, and (3) 
devise a simple ranking of rural and urban communities. At the end of each of these rankings we then asked for the criteria used by the participants to make the ranking. A ranking of criteria for wellbeing was also introduced for triangulation purposes to 17 residents. Participants had to divide criteria selected from the semistructured interviews into four major groups ranging to very important to unimportant for a good life.

\section{Trend lines}

Trend lines were used for a more detailed assessment of the main changes in the community identified in the semistructured interviews. Trend lines were applied to 11 residents. This tool was applied in Igreja in three different meetings organized by the researchers with young people of both genders, middle-aged and older women, and middle-aged and older men. Members of each group were selected using diversity, snowball, and accidental sampling. This tool was not applied to the other localities because the most important changes perceived in the semistructured interviews were common to all localities. A graph was drawn for each trend. The idea was to encourage discussion of the perceived causes for each trend, to discover linkages between trends, and to elicit people's perspectives on whether these trends were likely to change in the future.

\section{Scoring and ranking of agro-ecosystem resources and landscape scoring}

We also performed an exercise to score and rank agro-ecosystem resources to encourage the identification of ecosystem services by the community and to understand which services are more valued in terms of well-being. Forty-one individuals were sampled using accidental sampling, quota sampling, diversity sampling, and snowball sampling, e.g., by asking local residents to name people associated with different activities such as hunting, farming, commerce, etc. We used photographic cards to represent eight agroecosystem resources: water springs, the Vez River, cattle, agricultural fields, scrubland baldio, forest baldio, biodiversity, and the terraced socalcos landscape. Each participant received three stones and distributed them on the cards representing the resources they considered the most important for well-being. Participants were encouraged to explain the reasons for their choices. At the end of the exercise, the total for each resource was calculated, and the resources were ranked based on these scores. These rankings were then discussed, including positive and negative criteria associated with each resource.

The landscape preferences of the residents were assessed using a scoring exercise. Thirty-nine individuals were selected using accidental, diversity, snowball, and quota sampling. In the exercise, people had to score five different landscapes: agricultural fields, scrubland, oak forest, pine forest, and eucalyptus forest. Each participant was asked to choose his or her preferred landscape(s) and explain the reasons for these choices. A discussion based on the choices made was encouraged, including positive and negative criteria associated with each landscape.

\section{Biodiversity known to local residents}

Finally, we asked 21 residents to enumerate local species of plants, birds, mammals, reptiles, and amphibians as well as their main characteristics to assess local knowledge about biodiversity. Five of the individuals in this sample were selected by asking residents in each locality to name individuals with a good knowledge of different species; the others were selected using accidental and diversity sampling to ensure that both genders and younger people were included.

\section{Scenarios}

One final meeting was held to present the main findings of the study and to conduct a scenarios exercise with representatives of organizations who had implemented or were in the process of implementing projects in Sistelo. These organizations included the forestry association ATLÂNTICA, a regional development association called the Associação Regional de Desenvolvimento do Alto Lima, the regional office of the Portuguese Red Cross, and the National Park of Peneda-Gerês. In this exercise, these representatives were asked to imagine plausible scenarios for Sistelo in a timeline of $40 \mathrm{yr}$, the consequences for ecosystem services and human well-being, and the drivers of change associated with each scenario. 
Fig. 5. The criteria for human well-being most often cited by the participants in the areas identified by the Millennium Ecosystem Assessment. The criteria on the left all feed into freedom of choice and action.

\section{Material well-being}

Money income; acoess to goods and services; assets such as house, cattle, and fields; quantity and quality of food

\section{Bodily well-being}

Health, leisure, youth, capacity to work

\section{Social well-being}

Loneliness, mutual help, conviviality, joy

\section{Freedom of choice and action}

\section{Enlargement of} choices

\section{Security}

Security from retirement pensions, safe environment, air and water quality, tranquillity

\section{RESULTS}

\section{Local criteria for human well-being}

Nearly 40 different criteria for human well-being were identified. We organized the most frequently mentioned criteria (Figs. 5 and 6) according to the components of well-being considered in the conceptual framework of the Millennium Ecosystem Assessment (Millennium Ecosystem Assessment 2003).

Material well-being, or criteria related to it, was always cited by individuals when discussing wellbeing and improvements in living conditions. Income was universally considered a determinant of well-being. However, it is important to note that local participants distinguished between wealth and well-being: when speaking about well-being, people always referred to other criteria besides wealth. Access to goods and services was also very important for well-being. Participants consistently mentioned the importance of having better roads to improve access to goods and services from the outside. Access to services at the local level was also stressed. Assets such as a house, cattle, fields, or a house garden were considered important. Because of the shortage of labor, fields have become less important than they once were, but they were still a valuable source of food as a complement to food purchased from the outside. Nevertheless, some people felt that having fields was negatively related to well-being because fields mean more work and more worries. This feeling was expressed in statements such as "Before those who had fields were rich, today people who have fields are poor." People referred to the importance of food abundance but also of food quality. Some people were of the opinion that, although nowadays there is no shortage of food, the quality of the available food is worse because of the chemicals and artificial substances used in food production that could be harmful to human health.

Physical well-being, or criteria related to it, was also mentioned by everyone. In particular, local residents stressed health, leisure or not having to work so hard, the capacity to work, and not being old as fundamental aspects of a good life.

Criteria related to social well-being were widely mentioned as a critical aspect of a good life. Local residents emphasized the problem of loneliness and 
Fig. 6. Expressions of well-being and poverty used by the residents of Sistelo.

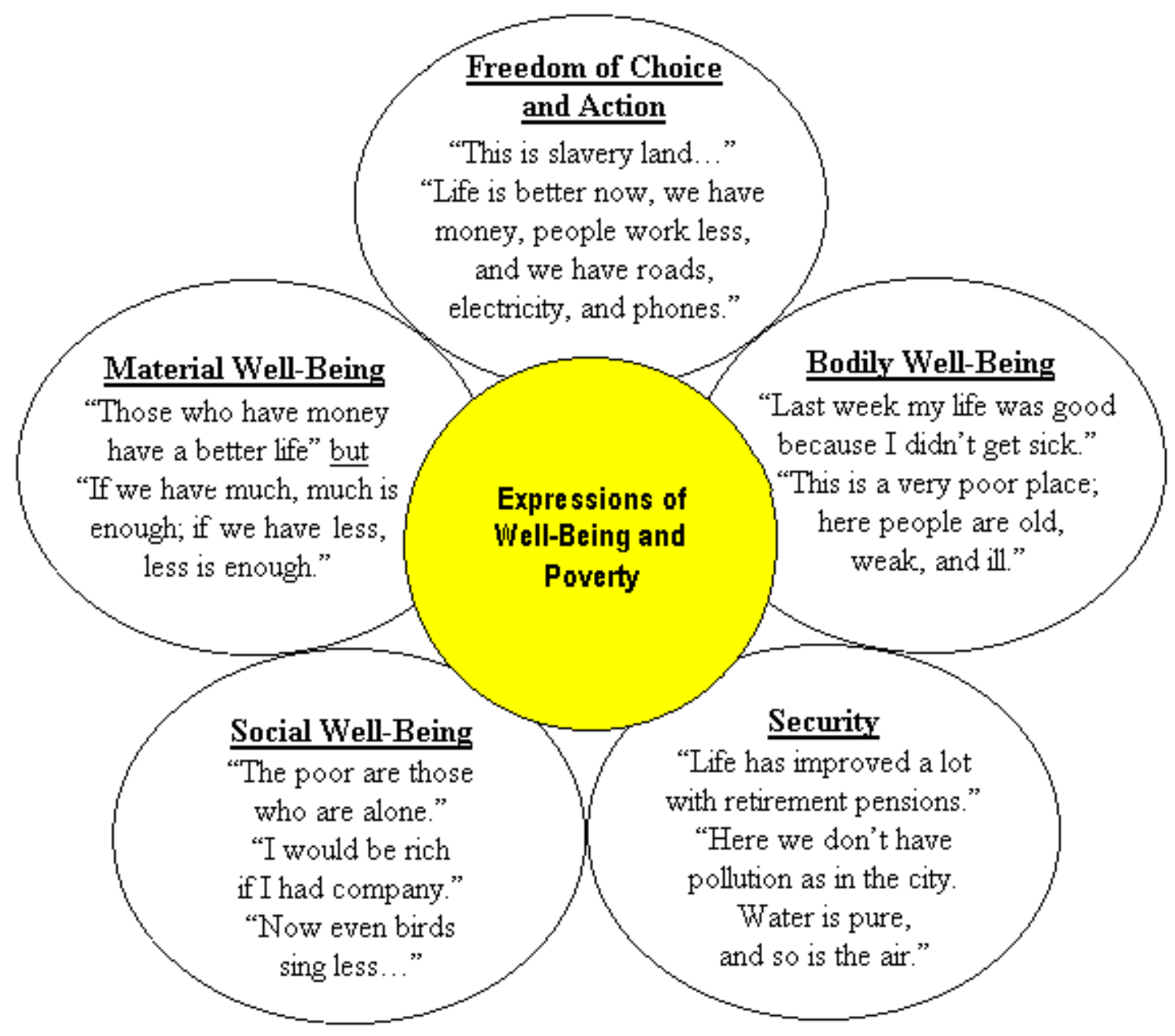

the importance of living with family. Mutual help, conviviality, and joy were also considered important for a good life.

With regard to security, most people referred to aspects such as the security attained from retirement pensions, tranquility, and a safe environment. The importance of retirement pensions was particularly stressed in the context of security in old age. The importance of tranquility and a safe environment was emphasized when individuals compared wellbeing in Sistelo with the situation in urban communities. People gave the example of air and water quality as an advantage of living in Sistelo.
Freedom of choice and action can be defined as the "freedom to lead the kind of lives people have reason to value" (Sen 1999). Many people considered freedom an important component of well-being. Some local residents used this criterion to justify the differences between people. For them, at least some of those differences, e.g., choosing not to have piped water in the house, were considered to be the result of a conscious decision. Although freedom of choice and action is closely related to the other four constituents of well-being, people emphasized that they had more choices now than in the past, particularly with regard to having more cash income 
and improved access to goods and services. The expressions "land of slavery" and "slave work, $\& \# 8221$ both of which were frequently repeated by the study participants, reflect the importance of the choices now available because of mobility and income sources unrelated to agriculture. Education, which can be considered important for the enhancement of freedom of choice and action, was rarely referred to when ranking individuals in different groups of well-being, although it was almost universally classified as very important when ranking the criteria for well-being. Education was considered important mainly because it conferred the ability to read and write.

The great majority of participants reported that they are generally better off now than $30 \mathrm{yr}$ ago because of improvements in criteria related to material wellbeing and the enhancement of choices. Nevertheless, people also reported a deteriorating situation with regard to some of the criteria related to well-being, notably those related to social wellbeing. People stated, for example, that the community is now worse off in terms of joy, conviviality, and mutual help. The reasons stated for this decline were the decrease in and the aging of the population and the disappearance of some traditional practices related to agriculture. These traditional practices consisted of regular gatherings of people to help work each other's fields and to accomplish certain production activities such as fiadas (spinning wool) and desfolhadas (stripping corn leaves). During fiadas and desfolhadas, people usually sang and danced together. These traditional activities had an important role in the enhancement of the social capital, broadly defined as social networks and the associated norms and values (Grootaert and Bastelaer 2001), that enables people to coordinate actions and to achieve desired goals (Narayan 1999).

Interestingly, most people (36 out of 39 residents) preferred to live in Sistelo rather than in more urbanized areas. The criteria used to justify this choice were a healthy environment, tranquility, the ability to be self-sufficient, a sense of place, and freedom.

\section{Agro-ecosystem resources}

The agro-ecosystem resources that were most frequently mentioned in the semistructured interviews as being affected by important changes were cultivated fields, livestock animals, and forest (Table 3). Local residents indicated that these resources had been in decline for the previous 30 yr. Their perception of this trend is corroborated by inventories and other surveys (Caldas 1982, Medeiros 1984, IGP 1990, INE 1989, 1999, ARDAL 2002). Data from the National Institute of Statistics show that the amount of arable open land decreased from 176 ha in 1989 to 55 ha in 1999, and that the amount of permanent pasture open land excluding the baldio common area increased from 15 ha in 1989 to 181 ha in 1999 (INE 1989, 1999). This shows that most of the recently abandoned cultivated areas are being converted to pasture. With regard to livestock, from 1972 to 1999 there was a $28 \%$ reduction in the number of head of cattle and a 34\% decrease in the number of sheep (Medeiros 1984, INE 1999). However, it is important to note that in the period from 1999 to 2002 there was an increase of $14 \%$ in the number of cattle (ARDAL 2002). Total forest area in the Arcos de Valdevez municipality, which encompasses Sistelo, decreased $6 \%$ from 1974 to 1990 , with a $21 \%$ reduction in the amount of pine forest over the same period (IGP 1990).

With the exception of the forest, in which losses were caused mainly by forest fires, the shrinking and aging population was considered the main reason for the reduction in the amount of agroecosystem resources (Table 3). Furthermore, the people of Sistelo believe that this decline is irreversible. "Sistelo is dead!" was the expression used to illustrate the deterministic character of these trends and the absence of a future.

The perceptions of the local people with regard to trends in biodiversity were not assessed in this study because local residents did not refer it as a significant change. Nevertheless, during semistructured interviews we asked key informants about perceived trends in numbers of wild animals. There was a great deal of variation in the responses. The only consistent response was that some hunted species were decreasing. Data from neighboring areas supported this perception. For instance, the grey partridge (Perdix perdix) has become extinct in the area, and the hare (Lepus granatensis) has become extremely rare (Grupo de Trabalho Agro-Ambiental 2002).

Cattle, agricultural fields, and scrubland baldio or commons were ranked as the most important resources for well-being (Table 4). Cattle were 
Table 3. Trends in agro-ecosystem resources identified in the semistructured interviews and by means of inventories and other surveys, and the main causes of those trends according to the semistructured interviews and trend lines exercises.

\begin{tabular}{llll}
\hline $\begin{array}{l}\text { Agro-ecosystem } \\
\text { resources }\end{array}$ & $\begin{array}{l}\text { Trend perceived } \\
\text { by locals }\end{array}$ & $\begin{array}{l}\text { Trend based } \\
\text { on objective } \\
\text { indicators }\end{array}$ & Causes \\
\hline Cultivated fields & $\downarrow$ & $\downarrow$ & $\begin{array}{l}\text { Decreasing and aging population } \\
\text { High production costs }\end{array}$ \\
Cattle & $\downarrow$ & $\begin{array}{l}\text { Flood damage to irrigation channels } \\
\text { Decreasing and aging population. Since } \\
\text { Goats and sheep }\end{array}$ & $\begin{array}{l}\text { 1999, this downward trend has started to } \\
\text { reverse, with an increase in the number of } \\
\text { head of cattle because of subsidies. }\end{array}$ \\
& $\downarrow$ & $\begin{array}{l}\text { State appropriation of the community } \\
\text { pasture in the 1940s } \\
\text { Decreasing and aging population }\end{array}$ \\
& $\downarrow$ & $\begin{array}{l}\text { Occurrence of fires } \\
\text { Insufficient monitoring of forest areas }\end{array}$ \\
\hline
\end{tabular}

considered an important source of income because of agricultural subsidies. In addition to the economic importance of this resource, people also had an emotional attachment to livestock and to pastoral practices. Agricultural fields were referred to as important by most of the participants. However, as mentioned in the well-being section, some people also considered the possession of agricultural fields to be a source of discomfort because they had to worry about maintaining and clearing them. Scrubland baldio was considered a very important source of fuel and pasture, especially by people who did not own their own land. The statement "Baldio belongs to the poor!\&\#8221 was often used by the local residents as an example of the importance that this resource has to the people of Sistelo. The regulating services provided by the forest that were deemed important to well-being were air purification and a healthy environment. In fact, few regulating services were mentioned throughout this exercise. Water springs were pointed out as important because of their role in the irrigation of agricultural fields. In addition, the provision of drinking water was also often mentioned as a service provided by water springs. In contrast, the Vez River was mentioned as important both for the provisioning of water and for cultural and recreational services. The landscape of the socalcos did not seem to be important to the people of Sistelo despite its general appeal to outsiders. In fact, most people answered "yes" to a hypothetical question about whether or not they would like to see the socalcos disappear, because they associate these terraces with a great deal of hard work.

The residents surveyed did not immediately think of biodiversity as something important to their wellbeing, although in the ranking exercise some did refer to biodiversity as a priority in the maintenance of a healthy and clean environment. People had conflicting feelings about biodiversity: on the one hand, they appreciated the beauty of biodiversity, mainly of birds and plants, the feeling of joy provided by bird songs, and the utilitarian value of certain plants, particularly those that have medical properties. On the other hand, people felt that some of these animals and plants were harmful to agropastoral practices. For example, the wild-boar was associated with crop damage, and the wolf with the loss of livestock. In the species list exercise, 12 participants identified a total of 80 plant species, 26 bird species, 16 mammalian species, seven reptile species, and three amphibian species. Medical properties were recognized in 26 plant species, mainly by older people who had used them in the past when they had no access to modern medicines. 
Table 4. Combined results of agro-ecosystem resources scoring and ranking. Agro-ecosystem resources are listed in decreasing order of preference.

\begin{tabular}{|c|c|}
\hline $\begin{array}{l}\text { Agro-ecosystem } \\
\text { resources }\end{array}$ & Services provided \\
\hline Cattle & $\begin{array}{l}\text { Income } \\
\text { Pleasure and joy } \\
\text { Manure to fertilize the fields }\end{array}$ \\
\hline Agricultural fields & $\begin{array}{l}\text { Food } \\
\text { Income } \\
\text { Fodder }\end{array}$ \\
\hline Scrubland baldio & $\begin{array}{l}\text { Wood, fuel, and fodder } \\
\text { Food for the hunt animals }\end{array}$ \\
\hline Forest/forested baldio & $\begin{array}{l}\text { Wood, fuel, and fodder } \\
\text { Income to the parish } \\
\text { Air purification } \\
\text { Healthy environment } \\
\text { Water springs } \\
\text { Oxygen }\end{array}$ \\
\hline Water springs & $\begin{array}{l}\text { Water for irrigation } \\
\text { Potable water }\end{array}$ \\
\hline Vez River & $\begin{array}{l}\text { Water for irrigation } \\
\text { Cultural values: part of local history } \\
\text { and tradition } \\
\text { Fish } \\
\text { Healthy pure water } \\
\text { Recreational activities }\end{array}$ \\
\hline Terraced landscape & $\begin{array}{l}\text { Aesthetic value } \\
\text { Fodder } \\
\text { Available land }\end{array}$ \\
\hline Biodiversity & $\begin{array}{l}\text { Healthy environment } \\
\text { Herbs for tea and medicine } \\
\text { Aesthetic value } \\
\text { Hunt animals } \\
\text { Regulation of the food chain } \\
\text { Pasture } \\
\text { Joy and pleasure }\end{array}$ \\
\hline
\end{tabular}

The results of the landscape scoring demonstrated that agricultural fields and oak forest were the preferred landscapes (Table 5). Agricultural fields were favored mainly because they provide food and fodder. Local residents valued the oak (Quercus robur) because it provides high-quality wood and contributes to a healthy environment. Wood supply was also mentioned as a reason by participants who chose pine and eucalyptus forests. Many individuals justified not choosing eucalyptus forest, the least preferred landscape overall, because it absorbs great quantities of water. The scrubland areas were valued by local residents who stressed the importance of this landscape in the support of pastoral activities. Aesthetic values were rarely mentioned as the reason for choosing a particular landscape.

\section{Scenarios for the future}

Two main scenarios were developed in collaboration with local organizations. The first scenario corresponds to the continuation of the current trends of depopulation and agricultural abandonment in Sistelo in a society that is not concerned with the environment. The second scenario corresponds to a reversal of the current trends in an environmentally friendly society.

For most participants, the consequences of the total land abandonment scenario would be quite negative, both for most local ecosystem services and for human well-being. The two dominant themes of this scenario are: (1) the cessation of the activities of terrace maintenance as a result of abandonment and depopulation and (2) the development of scrubland vegetation associated with early successional stages. According to the participants, these two changes would present serious threats, including the potential for large-scale fires because of the characteristics of the new vegetation cover, the loss of soil through run-off erosion, and landslides caused by the progressive collapse of the terraces. The participants projected that, in $40 \mathrm{yr}$, local biodiversity would decrease. Land abandonment would lead to a more simplified landscape, with less variety of land-use types. Large-scale fires would have negative impacts on some species and speed up the homogenization of the landscape. These fires would be a consequence of the increase in scrubland vegetation in the abandoned agricultural fields, the loss of controlled burning practices, the decrease in grazing, and the decrease in wood and bush collection by local populations. There would be almost no local provision of food services. Water quality would improve because pollution sources associated with agricultural practices and human occupation would disappear. Recreational and cultural services would be negatively affected in this scenario: many of the hunted species associated with agricultural landscapes would decrease, cultural tourism associated with this man-made 
Table 5. Results of the landscape scoring, presented by decreasing order of preference.

\begin{tabular}{lll}
\hline \hline Landscape & Positive contributions & Negative contributions \\
\hline $\begin{array}{l}\text { Agricultural fields } \\
\text { (terraces) }\end{array}$ & Food & $\ldots$ \\
Oak forest & Fodder & $\ldots$ \\
& Healthy landscape & \\
Pine forest & High-quality wood & $\ldots$ \\
Scrubland & Wood & $\ldots$ \\
Eucalyptus forest & Fodder & $\ldots$ \\
\hline
\end{tabular}

landscape and its aesthetic value would decline, and, most importantly, this valued cultural landscape, with its associated knowledge, heritage values, and identity, would be lost. Considering the loss of these ecosystem services and the diminished security associated with natural hazards, the human wellbeing associated with the services provided by this landscape would be negatively affected.

In the second scenario, the reversal of agricultural abandonment trends in an environmentally friendly society would have positive impacts both on local ecosystem services and on human well-being. Depopulation trends would change direction as young, resourceful, educated people immigrated to the area, although that would happen only if Sistelo became a better place to live, with, e.g., better access to services, improved working conditions in agriculture based on new technologies and solutions applied to the traditional management of the landscape, and new employment opportunities associated with diversified activities and those with an increased value. Improvements of this type would also encourage local young people to stay. In this scenario, traditional and innovative forms of land use would be developed to produce the goods and services needed to meet the growing demand for high-quality traditional and organic products and for the amenities associated with natural, sport, and cultural tourism. Traditional knowledge would be respected and enriched by the knowledge brought by those young educated people in an interactive process. In an environmentally friendly society, backed by increasing environmental education and awareness, this diversified use of the territory would be guided by concerns about sustainability, and the unsustainable use of resources would be avoided. In this scenario, biodiversity would be maintained or even enhanced because of the sustainable, diversified use of territory; water quality would be maintained or slightly decrease because of human activities; and food supply services would increase. Tourism and recreational services associated with hunting and fishing would be maximized to sustainable levels. Cultural services would be enhanced because the resulting landscape would reflect traditional knowledge, heritage values, and cultural identity. Material well-being, health, social well-being, security, and freedom of choice for local people would improve because of both the changes in the local ecosystems and improvements in wellbeing criteria not directly related to ecosystem services. These latter improvements are an important condition for the development of this scenario. Human well-being would also improve for people outside Sistelo who benefit from ecosystem services from Sistelo, because of improved food quality, recreation, and enjoyment of aesthetic values.

\section{DISCUSSION}

\section{Human well-being and ecosystem services at the local level}

Although the local criteria for well-being identified in this study are context-dependent and exist in a unique combination, they present some commonalities, 
Fig. 7. The Millennium Assessment conceptual framework applied to Sistelo.

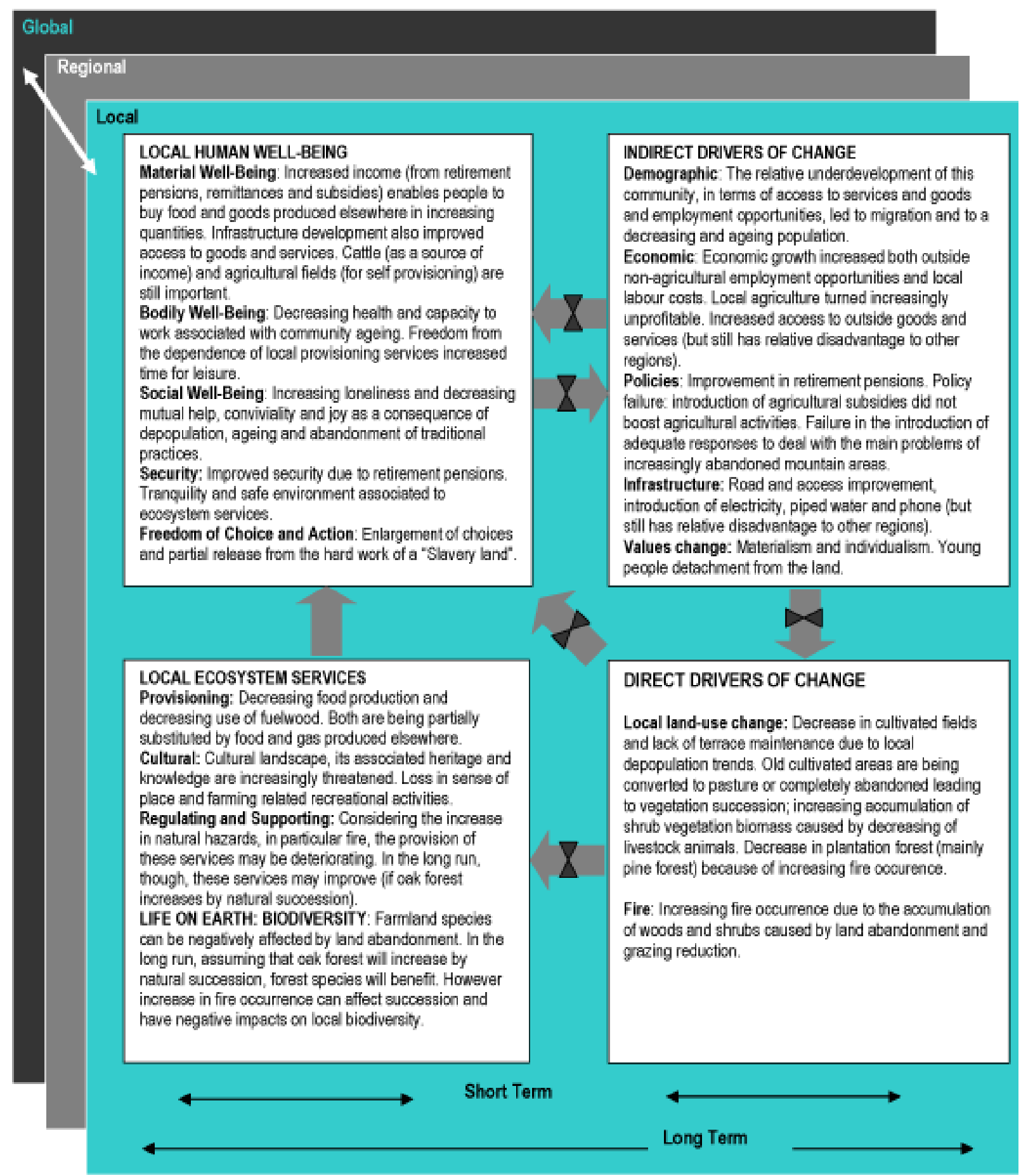


in terms of both criteria and constituents, to those identified in "Voices of the Poor," a series that gathered the views of 60,000 poor men and women from 60 countries (Narayan et al. 2000a,b). Several of the local criteria for well-being that were identified in our study did not depend directly on local ecosystem services; these include income from retirement pensions and nonagricultural work, access to goods and services, home ownership, age, leisure time, the capacity to work, loneliness, and, for the present generation, freedom of choice and action. However, other criteria were directly related to local ecosystem services, such as cattle as a source of income and fields for food self-sufficiency. These services have been decreasing in importance because of other sources of income, which allow people to replace local provisioning services with imported goods. The ability to make this substitution is considered a major improvement for the well-being of the community. The supply of fuelwood is valued because, for the great majority of households, a wood-burning fireplace is the only heating system.

The diminishing importance of food supply services could seem to contradict the results of the agroecosystem resources ranking (Table 4), considering how often the local residents referred to these services and their role as a potential source of income. This contradiction is only apparent. These services are still an important complement for local livelihoods, especially for those living on low retirement pensions. The ranking results may also be a reflection of an emphasis on direct uses of ecosystems, e.g., harvesting food and wood.

Health and a safe environment were also identified as local criteria for human well-being. For this reason, ecosystem services such as the purification of air and water, although not mentioned as often, were recognized as having great value. Local residents also cited several cultural services, in particular, recreation, a sense of place, cultural heritage, social traditions, and aesthetic values. Older people felt, for example, an emotional relationship with agro-pastoralism practices. For them, these practices also have a recreational value. People linked, at least partially, some criteria of social well-being to agricultural practices that have now disappeared but that formerly enhanced social capital and well-being. Furthermore, the Vez River is a very important symbol of cultural and local identity and figures in traditional songs and folktales as a river of pure and clear water.
Agriculture is based on the control of species diversity. Therefore, the role that biodiversity plays in more natural ecosystems may not always be valued by a community that practices agriculture, which may explain why biodiversity was rarely mentioned as a desirable resource. Even so, the species list exercise shows that the people of Sistelo have a good knowledge of local species and suggests that local biodiversity is important to them. Now, as community well-being becomes more detached from local ecosystem services, some of the more utilitarian knowledge of biodiversity, such as the identification of medicinal plants and of the best plants for pasture, will probably be lost.

Therefore, local people recognize and value a great variety of ecosystem services. Furthermore, the reasons why local residents prefer to live in Sistelo rather than in more urbanized areas were all related to ecosystem services. Similarly, in a survey conducted at the national level, $42 \%$ of respondents indicated that the countryside is the best place to live in Portugal. Life in the countryside was associated with tranquility, health, and natural beauty (Almeida 2000). However, at a national level, as in Sistelo, people continue to leave rural places in search of better material conditions, particularly employment opportunities and improved access to goods and services.

Sistelo's case provides a good example of the complexity of the linkages between ecosystem services and human well-being. It also shows the importance of material conditions not directly associated with ecosystem services that make people leave areas in which they feel that they have a superior quality of life.

\section{Human well-being and ecosystem services in the context of land abandonment}

To develop responses that increase both ecosystem services and human well-being, it is important to understand the linkages among local well-being criteria, trends in ecosystem services, and drivers of change (Fig. 7).

It is apparent that the downward trends in agroecosystem resources are the result of synergistic interactions among several causes. The decreasing and aging population seems to be the main indirect driver affecting the ecosystems and livelihoods of 
Sistelo. This driver is also affecting other mountainous areas of Portugal (Ferreira et al. 1999).

This study shows that, despite gains in material wellbeing and freedom of choice due mainly to emigrant remittances and improvements in the pension system, the depopulation of Sistelo has had negative consequences for local well-being, particularly social well-being. Furthermore, depopulation can also increase relative underdevelopment. With a shrinking population, the local delivery of public services such as schools and health care becomes increasingly unfeasible, for both economic and political reasons. This diminished access to public services along with lack of employment opportunities causes the continuous emigration of young people, reinforcing the abandonment trend and its social consequences. Negative consequences for well-being can also propagate elsewhere, with emigrants increasing population and environmental pressures in urban areas that are already stressed.

Depopulation and abandonment have led to significant changes in land use, which are perceived as having many negative consequences, both for human well-being and for ecosystem services. This perception was emphasized in the total abandonment scenario for Sistelo. It has also received support at the national level in recent reports from the Portuguese Ministry of Agriculture (Grupo de Trabalho Agro-Ambiental 2002, 2003) and at the European level in a study showing that, in 15 of 16 rural mountainous areas of Europe, depopulation and agricultural land abandonment had negative effects on biodiversity and the landscape (MacDonald et al. 2000).

For those ecosystem services most dependent on abundant human labor, the decrease in population and the subsequent abandonment of agricultural fields imply a decrease in the provision of those services. This is the case with the food provisioning services and the cultural services of the terraced landscape in Sistelo. The consequences of the downward trends in these services for human wellbeing are difficult to assess because of the increasing disconnect between human well-being and local ecosystem services. The causes for this are twofold. On the one hand, at the local level there has been a general improvement in those aspects of human well-being that are not strictly dependent on ecosystem services. On the other hand, there is a spatial disconnect between the location in which the ecosystem services are produced and the location of the people who benefit from those services. For instance, some of the services provided by Sistelo, such as the cultural landscape of socalcos or the regulation of the water quality in the Vez River, benefit people elsewhere.

In addition to the diminished provisioning and cultural services, the abandonment of traditional agricultural practices can lead to the accumulation of shrub vegetation biomass, which has the potential to contribute to an increased number of fires (Bernaldez 1991, Moreira et al. 2001b). This is closely related to the downward trend in the number of livestock animals, because grazing and the controlled burning practices associated with it have been for many years controlling fuel accumulation in mountain scrublands and forests. Moreira et al. $(2001 b)$ confirm the trend toward increased fire occurrence in this region, and local residents report that these fires are reducing the amount of forest area. Large-scale fires have negative impacts on the condition of local ecosystem services such as soil protection and climate regulation. Considering that total land abandonment will result in the neglect and ultimate collapse of the terraces on the mountain slopes (Grupo de Trabalho Agro-Ambiental 2002, Dunjó et al. 2003), landslides and soil loss will become serious problems. These problems along with increased fire occurrences will have direct negative impacts on human well-being, in particular, on environmental security. However, if a tree cover develops, the risk of these natural hazards may decrease in the long run (MacDonald et al. 2000), and ecosystem services such as carbon sequestration are likely to improve. Therefore, at least in the long term, there might be positive consequences of land abandonment for ecosystem services. However, some positive consequences of land abandonment could also occur in the short term, such as the improvements in water quality discussed in the total abandonment scenario.

The consequences of land abandonment for biodiversity are difficult to determine because the impact varies along temporal and spatial scales (MacDonald et al. 2000, Höchtl et al. 2005). For instance, the biodiversity of local flora at the species level can increase in the very early stages (Brown 1991), as one study in Sistelo has shown (C. Queiroz, H. M. Pereira, I. Gomes, and L. Vicente, unpublished manuscript), and then decrease from lower to higher successional stages (Höchtl et al. 2005). At the landscape level, a diversity of habitats such as those found in low-intensity agriculture 
landscapes is usually associated with high species diversity (van der Werff 1983, Fullbright 1996, Kerr et al. 2001). In the long run, if forest replaces abandoned fields, the species that are more dependent on the combination of habitats currently provided in the rural countryside will probably decrease and those associated with forests may increase (Parody et al. 2001). In Sistelo, some important hunted species associated with farmed environments will probably decrease, a trend already identified in the Parque Nacional da Peneda Gerês (Grupo de Trabalho Agro-Ambiental 2002). However, there could also be increases in species that have a long history of conflict with the local population, such as carnivorous mammals and reptiles. Land abandonment may also lead to the loss of local crop varieties and autochthonous breeds, some of which are already endangered (Grupo de Trabalho Agro-Ambiental 2002). The impacts of these changes on human well-being might be felt in different ways by different groups because of the ways in which those groups assign priorities to the different facets of biodiversity (Vermeulen and Koziell 2002).

Land abandonment in Sistelo will lead in the long run to the disappearance of the rural community and its associated knowledge and cultural heritage and to decreases in the variety of the local habitats. With this in mind, preservation of landscape diversity may be an important goal for cultural and environmental reasons. Considering the landscape preferences of the Sistelo people, the cultivated landscape has value both from a subsistence and a cultural point of view. Scrubland growth in the fields has a negative social connotation. Most people mention the importance of keeping fields clean even if they do not use them for crops or pasture any longer. This is consistent with the findings of a study conducted in Val Grande National Park (Höchtl et al. 2005) and with those of other studies (Hunziker 1995) reporting that, when agricultural fields are colonized by scrubland species, the local people often feel that they are losing their cultural heritage. Oak forest and cultivated fields were the preferred landscape, which means that later successional stages of land abandonment may also be valued. Nevertheless, local people value their landscape diversity, and, when asked, about half of the participants indicated more than one preferred landscape. The landscape of the socalcos is also recognized by outsiders as having a unique cultural and aesthetic value.
Different people can have different perceptions about landscape change based on their own preferences. Visitors may experience a positive feeling of naturalness associated with land abandonment and ecological succession but may regret the loss of the cultural landscape (Hunziker 1995, Höchtl et al. 2005).

Considering the consequences associated with current abandonment trends, the European Union and the national government implemented several measures to encourage agricultural practices and animal husbandry (ARDAL 2002). Nevertheless, although there has been a recent increase in the number of bovines, these incentives do not seem to be enough to boost agricultural activities and keep people in mountainous rural areas. The reality is that the mountain areas of Portugal "... have always been among the least developed areas of the country" (Ferreira et al. 1999). Limitations to improvements in agricultural productivity because of the physical characteristics of mountainous regions are negatively reinforced by socioeconomic disadvantages, both in terms of access to key infrastructures and services and the lack of alternatives to agriculture for making a living. Today, one of the main contraints to improving agriculture productivity in mountainous areas seems to be the difficulties related to mechanization. In fact, there are few fields in Sistelo that are large and accessible enough for the use of machines.

In addition to the terrain constraints limiting the improvement of agro-pastoralism practices, people stated that a lack of incentives to produce was another impediment to reviving agriculture. With the globalization of markets, people have access to products from other countries and other regions of Portugal, and the high production costs of local products prevent them from obtaining a competitive position in the market. This also explains why most of the young people who still live in Sistelo work in outside structures such as factories or other companies in the nearest village. For those young people, agriculture is very hard work for which the return does not justify the effort.

Land abandonment and demographic trends in mountainous areas of Portugal and other regions of Europe are serious problems that must be monitored. Depending on the cultural and environmental goals, there are two possible strategies for dealing with these problems. One, which combines cultural and environmental goals, 
is illustrated in the "inversion of trends scenario" for Sistelo and would require approaches designed to prevent abandonment and promote an environmentally friendly use of the land. The other strategy would emphasize the restoration of native forest but would require management measures to avoid the natural hazards illustrated in the current trends scenario. This strategy should be designed to achieve desired goals for ecosystem services and should be complemented by measures to help the population cope with isolation and ageing, for instance, by making access to health services easier. Each of these two strategies poses specific challenges and should be assessed in the larger-scale contexts of the mountainous regions of Portugal and Mediterranean Europe.

Responses to this article can be read online at: http://www.ecologyandsociety.org/vollo/iss2/art14/responses/

\section{Acknowledgments:}

The authors are grateful to the people of Sistelo, in particular those who took part in this research study. We would like to thank Inês Gomes for her help with the field work and Tiago Domingos and other members of the Portugal Millennium Assessment team for enlightening discussions.

\section{LITERATURE CITED}

Almeida, J. F. 2000. Os portugueses e o ambiente: inquérito nacional âs representações e práticas dos portugueses sobre o ambiente. Celta Editora, Lisbon, Portugal.

\section{Associação Regional de Desenvolvimento do Alto} Lima (ÁRDAL). 2002. Núcleo rural de Sistelo; candidatura ao Programa Operacional Regional, Medida Agricultura e Desenvolvimento Rural, Acção 7: valorização do ambiente e património rural. ARDAL, Arcos de Valdevez, Portugal.

Baudry, J. 1991. Ecological consequences of grazing extensification and land abandonment: role of interactions between environment, society and techniques. Options Méditerranéennes-Série
Séminaires 15:13-19.

Bernaldez, F. G. 1991. Ecological consequences of the abandonment of traditional land use systems in central Spain. Options Méditerranéennes-Série Séminaires 15:23-29.

Bignal, E., and D. McCracken. 1996. Lowintensity farming systems in the conservation of the countryside. Journal of Applied Ecology $\mathbf{3 3}$ (6):413-424.

Brown, V. 1991. Early successional changes after land abandonment: the need for research. Options Méditerranéennes-Série Séminaires 15:97-101.

Burel, F., and J. Baudry. 1995. Species biodiversity in changing agricultural landscapes: a case study in the Pays d'Auge, France. Agriculture Ecosystems and Environment 55(3):193-200.

Caldas, J. 1982. Pequenas explorações agrícolas familiares no concelho de Arcos de Valdevez: hipóteses para um estudo. Terras de Val de Vez 2 (Separatum).

Chambers, R. 1992. Rural appraisal: rapid, relaxed, and participatory. Institute of Development Studies Discussion Paper Number 31. Institute of Development Studies, Brighton, UK.

Chambers, R. 2003. Whose reality counts? Putting the first last. ITDG Publishing, London, UK.

Correia, T. 1993. Land abandonment: changes in the land use patterns around the Mediterranean basin. Cahiers Options Méditerranéennes 1:97-112.

Daily, G. C. 1997. Nature's services: societal dependence on natural ecosystems. Island Press, Washington, D.C., USA.

Deutsch, L., C. Folke, and K. Skanberg. 2003. The critical natural capital of ecosystem performance as insurance for human well-being. Ecological Economics 44:205-217.

Dunjó, G., G. Pardini, and M. Gispert. 2003. Land use change effects on abandoned terraced soils in a Mediterranean catchment, NE Spain. Catena 52:23-37.

Farina, A. 1991. Recent changes of the mosaic patterns in a montane landscape, (north Italy) and 
consequences on vertebrate fauna. Options Méditerranéennes-Série Séminaires 15:121-134.

Farina, A. 1997. Landscape structure and breeding bird distribution in a sub-Mediterranean agroecosystem. Landscape Ecology 12(6):365-378.

Ferreira, J., M. Roca, and E. Ventura. 1999. Prospects for sustainable development in mountain areas in Portugal: conceptual and policy-related issues. Pages 163-173 in I. Bowler, C. Bryant, and A. Firmino, editors. Progress in research on sustainable rural systems. International Geographical Commision on "Sustainability of Rural System" Série Estudos Number 2. Centro de Estudos de Geografia e Planeamento Regional, Universidade de Lisboa, Lisbon, Portugal.

Folke, C., C. Fabricius, L. Schultz, G. Cundill, C. Queiroz, Y. Gokhale, A. Marin, E. Camac, S. Chandola, M. Tawfic, B. Talukdar, A. Argumedo, and F. Torres. 2005. Communities, ecosystems and livelihoods. In D. Capistrano and C. Samper, editors. Sub-global assessments of the Millennium Ecosystem Assessment. Island Press, Washington, D.C., USA, in press.

Fullbright, T. E. 1996. Viewpoint: a theoretical basis for planning woody plant control to maintain species diversity. Journal of Range Management 49 (6):554-559.

Graça, L. 1996. Regadios tradicionais nas montanhas do norte de Portugal (Serra da Penedaum caso exemplar). P. Arroyo Agudo and F. J. Martínez Gil, editors. El agua a debate desde la universidad; hacia una nueva cultura del agua. Institución Fernando el Católico, Zaragoza, Spain. [online] URL:

http://www.us.es/ciberico/archivos acrobat/zaraponen7/ archer.pdf.

Grootaert, C., and T. Bastelaer. 2001. Understanding and measuring social capital: a synthesis of findings and recommendations from the Social Capital Initiative. Social Capital Initiative Working Paper Number 24. World Bank, Washington, D.C., USA.

Grupo de Trabalho Agro-Ambiental. 2002. Plano zonal agro-ambiental do Parque Nacional da Peneda Gerês; Plano de Desenvolvimento Rural de Portugal Continental. [online] URL:

http://www.min-agricultura.pt/oportal/extent/docs/
FOLDER/PROT TEMAS/F AMBIENTE/ MADRPCNT GTAA/PZ Peneda Gerez.pdf.

Grupo de Trabalho Agro-Ambiental. 2003. $O$ abandono da actividade agrícola. Ministério da Agricultura, Desenvolvimento Rural e Pescas, Lisbon, Portugal.

Höchtl, F., S. Lehringer, and W. Konold. 2005. "Wilderness": what it means when it becomes a reality-a case study from the southwestern Alps. Landscape and Urban Planning 70:85-95.

Hunziker, M. 1995. The spontaneous reafforestation in abandoned agricultural lands: perception and aesthetical assessment by locals and tourists. Landscape and Urban Planning 31:399-410.

Instituto Geográfico Português (IGP). 1990. Carta de ocupação do Solo-COS'90. IGP, Lisbon, Portugal.

Instituto Nacional de Estatística (INE). 1964. $X$ recenseamento geral da população. INE, Lisbon, Portugal.

Instituto Nacional de Estatística (INE). 1989. Recenseamento geral da agricultura. INE, Lisbon, Portugal.

Instituto Nacional de Estatística (INE). 1999. Recenseamento geral da agricultura. INE, Lisbon, Portugal.

Instituto Nacional de Estatística (INE). 2001. XIV recenseamento geral da população. INE, Lisbon, Portugal.

Kerr, J. T., T. Southwood, and J. Cihlar. 2001. Remotely sensed habitat diversity predicts butterfly species richness and community similarity in Canada. Proceedings of the National Academy of Science 98:11365-11370.

MacDonald, D., J. Crabtree, G. Wiesinger, T. Dax, N. Stamou, P. Fleury, J. Lazpita, and A. Gibon. 2000. Agricultural abandonment in mountain areas of Europe: environmental consequences and policy response. Journal of Environmental Management 59(1):47-69.

McMichael, T., B. Scholes, M. Hefny, E. Pereira, C. Palm, and S. Foale. 2005. Linking ecosystem services and human well-being in subglobal 
assessments. In D. Capistrano and C. Samper, editors. Sub-global assessments of the Millennium Ecosystem Assessment. Island Press, Washington, D.C., USA, in press.

Medeiros, I. 1984. Estruturas pastoris $e$ povoamento na Serra da Peneda. Centro de Estudos Geográficos, Lisbon, Portugal.

Michaelidou, M., D. Decker, and J. Lassoie. 2002. The interdependence of ecosystem and community viability: a theoretical framework to guide research and application. Society and Natural Resources 15:599-616.

Millennium Ecosystem Assessment. 2003. Ecosystems and human well-being; a framework for assessment. Island Press, Washington, D.C., USA.

Moreira, F., P. Ferreira, F. Regoand, and S. Bunting. 2001a. Landscape changes and breeding bird assemblages in northwestern Portugal: the role of fire. Landscape Ecology 16(2):175-187.

Moreira, F., F. Rego, and P. Ferreira. $2001 b$. Temporal (1958-1995) pattern of change in a cultural landscape of northwestern Portugal: implications for fire occurrence. Landscape Ecology 16:557-567.

Narayan, D. 1996. Toward participatory research. World Bank Technical Paper Number 307. World Bank, Washington, D.C., USA.

Narayan, D. 1999. Bonds and bridges: social capital and poverty. Policy Research Working Paper Number 2167. Poverty Reduction and Economic Management Network, World Bank, Washington, D.C., USA.

Narayan, D., R. Patel, K.. Schafft, A. Rademacher, and S. Koch-Shulte. 2000a. Voices of the poor: can anyone hear us? Oxford University Press, New York, New York, USA.

Narayan, D., R. Chambers, M. Shah, and P. Petesch. 2000b. Voices of the poor: crying out for change. Oxford University Press, New York, New York, USA.

Norton, A., B. Bird, K. Brock, M. Kakande, and C. Turk. 2001. A rough guide to PPAs: participatory povery assessment; an introduction to theory and practice. Overseas Development
Institute, London, UK.

Parody, J. M.,F. J. Cuthbert, and E. Decker. 2001. The effect of 50 years of landscape change on species richness and community composition. Global Ecology and Biogeography 10(3):305-313.

Pereira, E. 2001. Implicações da evolução do conceito de pobreza para a luta contra a pobreza: uma reflexão. In J. Ferreira, J. Pereirinha, J. Silva, and $\mathrm{F}$. Mendes, editors. $O$ modelo latino de protecção social: reflexões sobre o estadoprovidência em Portugal, Espanha e Brasil. Instituto Superior de Economia e Gestão, Lisbon, Portugal.

Pereira, H. M., T. Domingos, and L. Vicente. 2003. Report on the user needs and response options. Portuguese Sub-Global Assessment of the Millennium Ecosystem Assessment. [online] URL: http://www.ecossistemas.org.

Rey, J. 2000: Território e povoamento. Pages 22-39 in L. Graça and H. dos Santos, editors. Cadernos da montanha: peneda 1. Direcção Regional de Agricultura de entre Douro e Minho, Braga, Portugal.

Rietbergen-McCracken, J., and D. Narayan. 1998. Participation and social assessment: tools and techniques. International Bank for Reconstruction and Development/World Bank, Washington, D.C., USA.

Salzman, J., B. H. Thompson, and G. C. Daily. 2001. Protecting ecosystem services: science, economics, and policy. Stanford Environmental Law Journal 20:309-332.

Sen, A. 1999. Desenvolvimento como liberdade. Companhia das Letras, São Paulo, Brazil.

Socio-Economic and Gender Analysis Programme (SEAGA). 2001. Field level handbook. FAO, Rome, Italy.

Sustainable Agriculture and Rural Livelihoods Programme. 1988-2001. Participatory learning and action. International Institute for Environment and Development, London, UK.

Van der Werff, H. 1983. Species number, area and habitat diversity in the Galapagos Islands. Vegetatio 54:167-175. 
Vermeulen, S., and I. Koziell. 2002. Integrating global and local values: a review of biodiversity assessment. Natural Resource Issues Paper Number 3. International Institute for Environment and Development, London, UK.

Wainger, L. A., and E. W. Price. 2004. Evaluating quality of life, economic vulnerabilities, and drivers of ecosystem change. Environmental Monitoring and Assessment 94(1/3):69-84. 